УДК 665.775:544.777+691.168

\title{
ВПЛИВ ДОБАВКИ ПОЛІМЕРНОГО ЛАТЕКСУ НА ФІЗИКО-МЕХАНІЧНІ ВЛАСТИВОСТІ БІТУМУ ТА АСФАЛЬТОБЕТОНУ
}

Канд. техн. наук С.В. Оксак

\section{ВЛИЯНИЕ ДОБАВКИ ПОЛИМЕРНОГО ЛАТЕКСА НА ФИЗИКО-МЕХАНИЧЕСКИЕ СВОЙСТВА БИТУМА И АСФАЛЬТОБЕТОНА}

Канд. техн. наук С.В. Оксак

\section{INFLUENCE OF POLYMER LATEX ADDITIVE ON PHYSICAL AND MECHANICAL PROPERTIES OF BITUMEN AND ASPHALT CONCRETE}

\author{
Cand. of techn. sciences S. Oksak
}

В статті розглянуто можливість використання полімерного латексу Butonal NS 198 для модифікації нафтового бітуму. Визначено оптимальні режими суміщення бітуму та латексу Butonal NS 198. Досліджені фізико-механічні властивості асфальтобетонів різних гранулометричних типів на традиційному бітумі та бітумі з добавкою полімерного латексу Butonal NS 198. Визначено вплив добавки полімерного латексу Butonal NS 198 на основні властивості бітуму БНД 60/90 та фізико-механічні властивості асфальтобетонів.

Ключові слова: бітум, полімерний латекс Butonal NS 198, модифікація, асфальтобетон, фізико-механічні властивості

B статье рассмотрена возможность использования полимерного латекса Butonal NS 198 для модификачии нефтяного битума. Определены оптимальные режимы совмещения битума и латекса Butonal NS 198. Исследовань физико-механические свойства асфальтобетонов различных гранулометрических типов на традиционном битуме и битуме c добавкой полимерного латекса Butonal NS 198. Определено влияние полимерного латекса Butonal NS 198 на основные свойства битума БНД 6090 и физико-механические свойства асфальтобетонов.

Ключевые слова: битум, полимерный латекс Butonal NS 198, модификация, асфальтобетон, физико-механические свойства

The influence of polymer latex Butonal NS 198 on the properties of petroleum bitumen BND 60/90. The optimum combination of modes of bitumen and latex Butonal NS 198. The effect of mixing time on the properties of the modified binder (penetration at $25{ }^{\circ} \mathrm{C}$, softening point, brittleness temperature and elasticity). The effect of the polymer latex on the binder optimal quantity and properties of asphalt concrete types different grading. The optimal quantity of binder increases with decreasing content of rubble, that the transition from asphalt type $A$ to type $G$. The adding of polymer latex in bitumen BND 60/90 increases the strength of asphalt concrete at 20 i 50 ${ }^{\circ} \mathrm{C}$, and the strength at $0{ }^{\circ} \mathrm{C}$ is decreases slightly. Established water resistance and strength characteristics increase of asphalt concrete with Butonal NS 198, which indicates an increase in the durability of the road surface with the use of this material. 
Keywords: bitumen, polymeric latex Butonal NS 198, modification, asphalt concrete, physical and mechanical properties

Вступ.

Складні природно-кліматичні умови, істотне за останні роки збільшення вантажних перевезень автотранспортом потребують якісно нових рішень по будівництву й утриманню дорожнього покриття, а саме технологіям, що значно підвищують його якість та збільшують міжремонтний період.

Однією 3 таких технологій $\epsilon$ застосування бітумів модифікованих полімерами різних видів. За обсягами застосування полімери розміщуються в такому порядку: термоеластопласти типу стирол-бутадієн-стиролу (SBS); термопласти типу етилен-вініл-ацетат (EVA), поліізобутилен, поліпропілен, різноманітні блоксополімери; полімерні латекси (SBR); тер полімери типу етіленгліціділакрілата (Elvaloy) [1].

Ця технологія масово використовується 3 1960-х років за кордоном [2] і в останні роки, усе більше поширюється в нашій країні.

Постановка проблеми у загальному вигляді та іï зв'язок із важливими науковими та практичними завданнями.

Модифікація бітумів синтетичними полімерами є досить складною технологією, що потребує застосування складного обладнання (колоїдні млини, гомогенезатори i т.д.) для забезпечення необхідної однорідності та якості модифікованого в'яжучого [3].

Тому застосування для модифікації бітумів полімерних латексів $\epsilon$ дуже перспективним напрямком, оскільки латекси вміщують в своєму складі диспергований полімер і тому легко суміщаються з бітумом на відміну від інших різновидів полімерів.

Аналіз останніх досліджень i публікацій.

Протягом багатьох років стиролбутадієнові дисперсії (SBR-HSL), відомі під маркою Butonal, сприяють значному поліпшенню експлуатаційних властивостей дорожніх бітумів (гаряче та холодне укладання). У Германії і США продукти, що реалізовуються під маркою Butonal, $\epsilon$ стандартними матеріалами для модифікації бітумів. Латекси 3 низькою температурою склування здатні забезпечити додаткову гнучкість при низьких температурах i додаткову зсувостійкість асфальтобетону при високих температурах. Однак враховуючи, що вітчизняні дорожні бітуми відрізняються від тих, що використовуються в США та країнах Західної Свропи питання вивчення впливу таких модифікаторів на властивості дорожніх бітумів, що застосовуються в Україні не вирішене.

Застосування синтетичних латексів дозволяє підвищити міцність, асфальтобетону на розтяг, зсувостійкість [4]. Добавка Butonal значною мірою підвищує в'язкість бітумного в'яжучого. Міцність на розтяг асфальтобетону при цьому зростає в 5- 6 раз, а ударна міцність при низьких температурах підвищується удвічі, що дозволяє понизити товщину шару покриття на 30-45 \%, зберігаючи необхідну працездатність конструкції.

Полімерні латекси застосовувались для покращення властивостей залишкових бітумів [5]. Вихідні залишкові бітуми не відповідали вимогам, що висуваються до нафтових дорожніх бітумів [6], але добавка 2-3 \% полімерного латексу дозволяє отримати в'яжуче, що повністю відповідає вказаним вимогам.

\section{Визначення мети та задачі} дослідження.

Метою цієї роботи $є$ дослідження впливу полімерного латексу Butonal NS 198 на властивості нафтового дорожнього бітуму БНД 60/90, а також асфальтобетонів різних гранулометричних типів згідно з [7].

Для досягнення поставленої мети необхідно вирішити наступні задачі:

- визначити оптимальний режим суміщення нафтового бітуму та полімерного латексу Butonal NS 198;

- встановити оптимальний вміст модифікованого бітуму в складі асфальтобетонів різних гранулометричних типів;

- вивчити фізико-механічні властивості асфальтобетонів на основі традиційного бітуму та бітуму 3 добавкою полімерного латексу Butonal NS 198.

Основна частина дослідження.

В якості об'єкту дослідження обрано нафтовий дорожній бітум найбільш розповсюдженої марки БНД 60/90, що 
використовується на всій території України та асфальтобетони різних гранулометричних типів.

Полімерний модифікатор (латекс) серії Butonal NS 198 (катіонний) виробництва BASF (США) належить до термоеластопластів типу СБР і $€$ водною дисперсією сополімерів бутадієн - стиролу, які містять конгломеровану сірку. Латекс Butonal NS 198 завдяки наявності катіонного емульгатору, окрім модифікації бітуму, покращує зчеплення бітумів 3 мінеральними матеріалами.

Об'єднання бітуму та полімерного латексу здійснювалося при температурі 180 ${ }^{\circ} \mathrm{C}$, кількість латексу Butonal NS 198 складала 4 \% (введення виконується дуже обережно, щоб не допустити спінення бітуму при його контакті з водою, яка міститься в латексі). Для визначення оптимального часу змішування досліджено вплив часу перемішування на властивості модифікованого в'яжучого. Отримані дані вказують на те, що вже після 0,5 години перемішування, ці показники практично не змінюються (рис. 1 та 2).

Тому час перемішування, що рекомендується виробником (1,5-2,5 години), можна дещо скоротити (до 1 години), що дозволить забезпечити повну розчинність полімерного латексу Butonal NS 198 в бітумі без зайвих енерговитрат та витрат часу. Скорочення часу перемішування скорочує час перебування бітуму у зоні високих температур $\left(180{ }^{\circ} \mathrm{C}\right)$, що зменшує ступінь старіння бітуму та бітумополімерного в'яжучого в цілому.

Властивості вихідного бітуму БНД 60/90 та бітуму модифікованого 4 \% латексу Butonal NS 198, отриманого перемішуванням протягом 1 години, та приведені в табл.1. Отримане бітумополімерне в'яжуче відповідає вимогам [8] для марки БМП 40/60-56 окрім температури розм’якшеності.

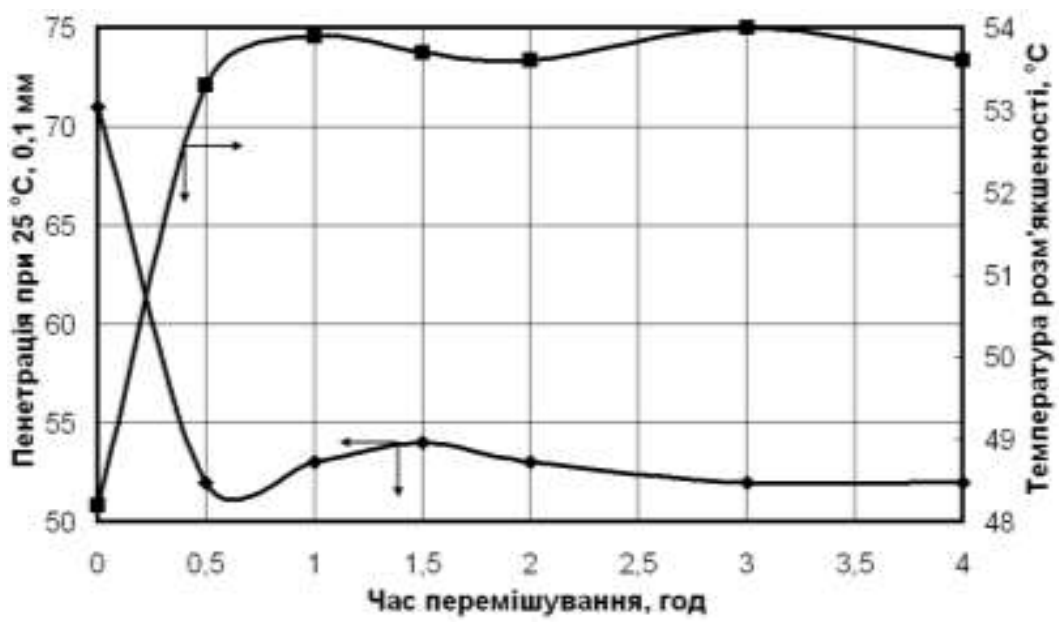

Рис. 1. Вплив часу перемішування на властивості отриманого модифікованого

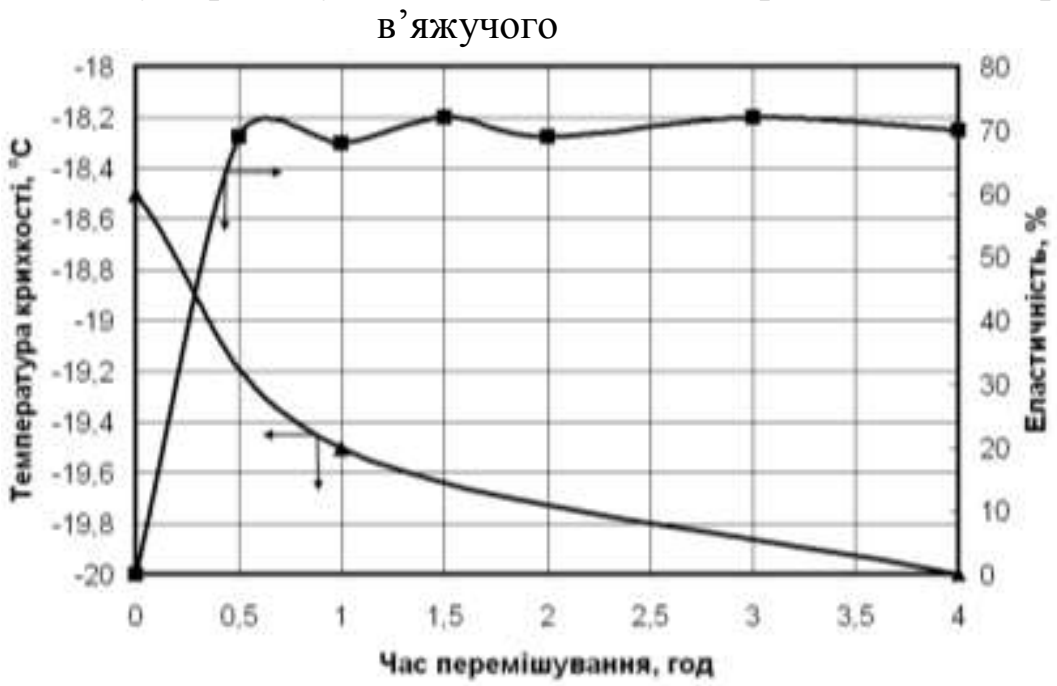

Рис. 2. Вплив часу перемішування на еластичність та температуру крихкості отриманого модифікованого в'яжучого 
Таблиця 1 - Властивості бітуму та бітуму, модифікованого полімером

\begin{tabular}{|l|c|c|}
\hline \multirow{2}{*}{ Показники } & \multicolumn{2}{|c|}{ В'яжуче } \\
\cline { 2 - 3 } & $\begin{array}{c}\text { БНД } \\
60 / 90\end{array}$ & $\begin{array}{c}\text { БНД 60/90+4 \% } \\
\text { Butonal NS 198 }\end{array}$ \\
\hline Пенетрація при температурі $25{ }^{\circ} \mathrm{C}, 0,1 \mathrm{~mm}$ & 71 & 53 \\
\hline Температура розм'якшеності, ${ }^{\circ} \mathrm{C}$ & 48,2 & 53,9 \\
\hline Температура крихкості, ${ }^{\circ} \mathrm{C}$ & $-18,5$ & $-19,5$ \\
\hline Розтяжність при температурі $25^{\circ} \mathrm{C}, \mathrm{cm}$ & $>100$ & $>100$ \\
\hline Еластичність, \% & 0 & 65 \\
\hline Для об’єктивної оцінки фізико- & Залежність & оптимального вмісту
\end{tabular}
механічних властивостей асфальтобетонів в'яжучого від його виду досліджувалась на необхідно вивчати такі бетони, які містять асфальтобетоні типу Б та приведена на рис. оптимальний вміст в’яжучого [9]. При 3-4. Для порівняння були приготовані суміші оптимальному вмісті в'яжучого на чистому бітумі БНД 60/90, на бітумі асфальтобетони характеризуються модифікованому 4 \% Butonal NS 198. максимальними значеннями фізикомеханічних властивостей.

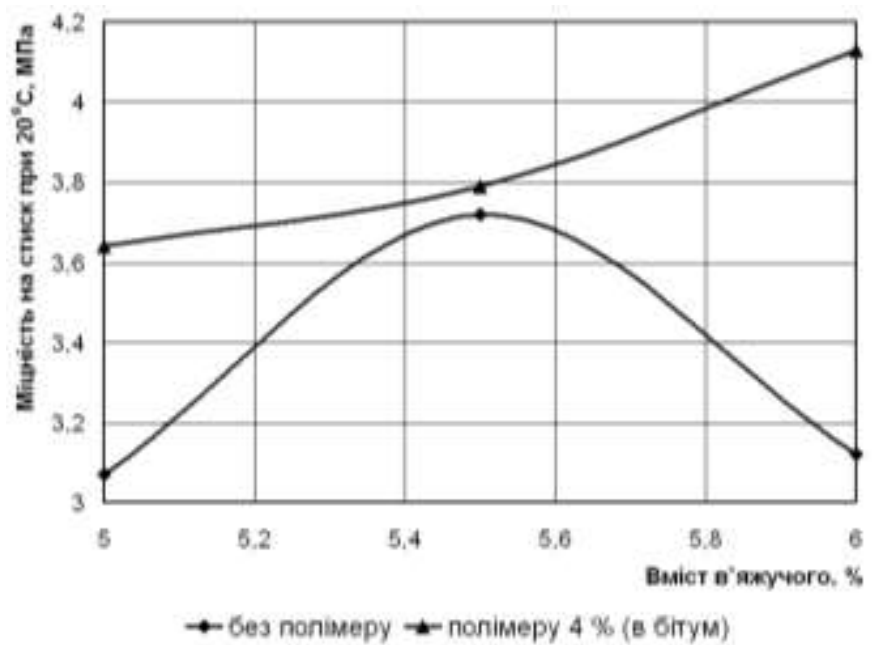

Рис. 3. Вплив вмісту в'яжучого на міцність асфальтобетону та асфальтополімербетону типу Б при $20^{\circ} \mathrm{C}$

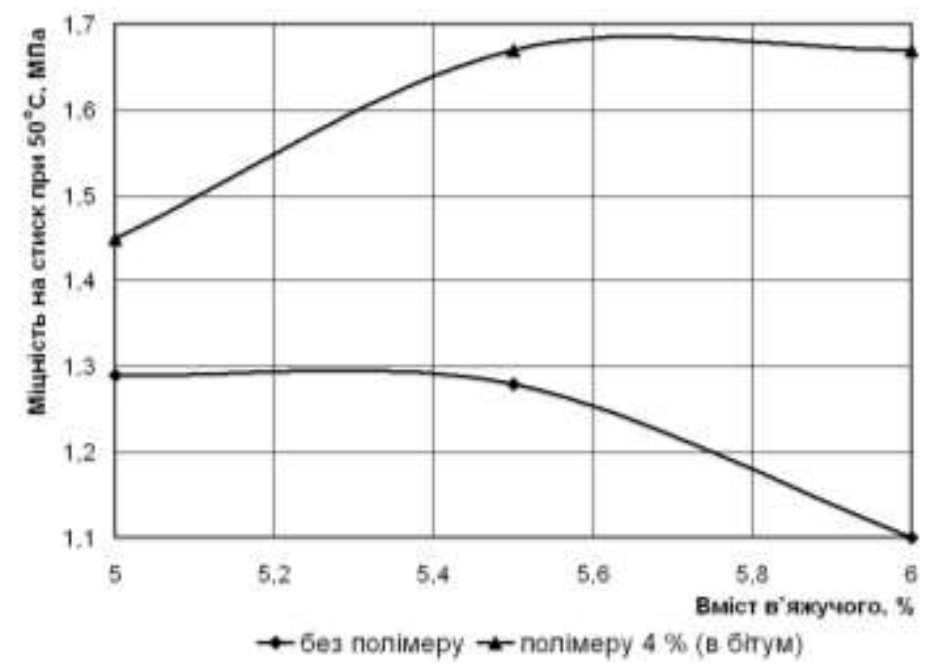

Рис. 4. Вплив вмісту в'яжучого на міцність асфальтобетону та асфальтополімербетону типу Б при $50^{\circ} \mathrm{C}$ 
Оптимальний вміст в'яжучого 3 додаванням полімеру в бітум підвищується, що може бути пов'язане зі збільшенням в'язкості в'яжучого.

Схожа ситуація спостерігається і для типів А, В і Г. Таким чином, оптимальний вміст в'яжучого при введенні полімеру підвищується наступним чином (табл. 2): для типу А: бітум БНД 60/90 - 5,0 \%; при модифікації бітуму 4 \% Butonal NS 198 5,4 \%; для типу Б: бітум БНД 60/90 - 5,5\%; при модифікації бітуму 4 \% Butonal NS 198 6,0 \%; для типу В: бітум БНД 60/90 - 6,0\%; при модифікації бітуму 4 \% Butonal NS 198 6,5 \%; для типу Г: бітум БНД 60/90 - 6,5\%; при модифікації бітуму 4 \% Butonal NS 198 $7,0 \%$.

Таблиця 2 - Фізико-механічні властивості асфальтобетону різних типів 3 оптимальним вмістом в'яжучого

\begin{tabular}{|c|c|c|c|c|c|c|c|c|c|c|c|}
\hline \multirow{2}{*}{$\begin{array}{l}\text { Тип } \\
\mathrm{a} / 6\end{array}$} & \multicolumn{2}{|l|}{ В'яжуче } & \multirow{2}{*}{$\begin{array}{c}\rho, \\
\kappa \Gamma / \mathrm{M}^{3}\end{array}$} & \multirow{2}{*}{$\begin{array}{l}\mathrm{W} \\
\%\end{array}$} & \multirow{2}{*}{$\begin{array}{l}\mathrm{R}_{20} \\
\mathrm{M \Pi а}\end{array}$} & \multirow{2}{*}{$\begin{array}{l}\mathrm{R}_{50} \\
\text { МПа }\end{array}$} & \multirow{2}{*}{$\begin{array}{l}\mathrm{R}_{0} \\
\mathrm{M \Pi а}\end{array}$} & \multirow[b]{2}{*}{$\mathrm{K}_{15}$} & \multirow[b]{2}{*}{$\mathrm{K}_{30}$} & \multirow{2}{*}{$\begin{array}{l}\mathrm{r}_{50} \\
\mathrm{M \Pi а}\end{array}$} & \multirow{2}{*}{$\begin{array}{c}\tau_{50} \\
\mathrm{M \Pi а}\end{array}$} \\
\hline & склад & $\begin{array}{c}\text { вміст, } \\
\%\end{array}$ & & & & & & & & & \\
\hline \multirow[b]{2}{*}{ A } & БНД 60/90 & 5,0 & 2331 & 3,8 & 2,99 & 0,97 & 9,24 & 0,80 & 0,73 & 0,092 & 0,111 \\
\hline & $\begin{array}{c}\text { (БНД 60/90 + } 4 \\
\% \text { Butonal) }\end{array}$ & 5,4 & 2338 & 3,4 & 3,92 & 1,24 & 9,10 & 0,84 & 0,78 & 0,132 & 0,153 \\
\hline \multirow[b]{2}{*}{ Б } & БНД 60/90 & 5,5 & 2365 & 2,8 & 3,72 & 1,28 & 10,34 & 0,80 & 0,76 & 0,114 & 0,148 \\
\hline & $\begin{array}{c}\text { (БНД 60/90 + } 4 \\
\% \text { Butonal) }\end{array}$ & 6,0 & 2370 & 2,3 & 4,13 & 1,67 & 9,51 & 0,91 & 0,85 & 0,176 & 0,207 \\
\hline \multirow[b]{2}{*}{ B } & БНД 60/90 & 6,0 & 2367 & 2,7 & 4,10 & 1,67 & 10,06 & 0,87 & 0,82 & 0,113 & 0,143 \\
\hline & $\begin{array}{c}\text { (БНД 60/90 + } 4 \\
\% \text { Butonal) }\end{array}$ & 6,5 & 2373 & 2,0 & 4,83 & 1,98 & 9,85 & 0,92 & 0,86 & 0,175 & 0,211 \\
\hline \multirow[b]{2}{*}{$\Gamma$} & БНД 60/90 & 6,5 & 2322 & 2,3 & 3,92 & 1,48 & 10,42 & 0,89 & 0,86 & 0,109 & 0,141 \\
\hline & $\begin{array}{c}\text { (БНД 60/90 + } 4 \\
\% \text { Butonal) }\end{array}$ & 7,0 & 2330 & 1,6 & 4,20 & 1,93 & 9,28 & 0,94 & 0,89 & 0,168 & 0,208 \\
\hline
\end{tabular}

Із введенням полімеру в бітум БНД 60/90 підвищується міцність асфальтобетонів при 20 і $50{ }^{\circ} \mathrm{C}$, а міцність при $0{ }^{\circ} \mathrm{C}$ дещо знижується, це може бути обумовлено невеликим зниженням температури крихкості бітуму при введені в нього полімеру. При введенні латексу у асфальтобетонну суміш показники асфальтобетону також зростають, але менш інтенсивно. Всі асфальтобетони за своїми властивостями повністю відповідають вимогам [7].

Стандартні показники міцності на стиск при 20 і $50{ }^{\circ} \mathrm{C}$ не завжди об'єктивно характеризують зсувостійкість асфальтобетону. У зв'язку з цим, були проведені дослідження за визначенням міцності на розтяг по твірній і на зсув при крученні асфальтобетонів. Ці показники $€$ більш чутливими до підсилюючої дії полімеру.

Зсувостійкість асфальтобетону $\epsilon$ найважливішим показником якості асфальтобетонного покриття. Висока зсувостійкість асфальтобетону попереджає утворення на покритті постійних деформацій у вигляді хвиль, колій, напливів, і таким чином забезпечує рівність дорожнього покриття. У країнах Західної і Центральної Європи попередження пластичної деформації асфальтобетонних покриттів розглядається як найважливіше завдання, над вирішенням якої працюють вчені i виробничники. В Україні пластичні деформації $\epsilon$ поширеним видом руйнування асфальтобетонних покриттів.

Iз введенням полімеру міцність асфальтобетону на зсув $\left(\tau_{50}\right)$ i розтяг по твірній ( $\left.\mathrm{r}_{50}\right)$ підвищуються (табл. 2).

Добавка полімеру також підвищує водостійкість асфальтобетону, так коефіцієнт водостійкості асфальтобетону на бітумі БНД 60/90 складає 0,80, а у асфальтобетону на бітумі модифікованому 4 $\%$ латексу $-0,90$. 


\section{Будівельні матеріали, конструкції та споруди}

\section{Висновки 3 дослідження і перспективи, подальший розвиток $\mathbf{y}$ даному напрямку.}

Застосування полімерного латексу Butonal NS 198, для модифікації бітумів покращує їх властивості, а саме підвищує консистенцію, підвищує температуру розм'якшення та дещо знижує температуру крихкості. Це призводить до розширення інтервалу пластичності бітуму. Зростає когезія бітуму та 3'являється еластичність.

Використання латексу Butonal NS 198 є менш енергоємним у порівнянні 3 іншими полімерними добавками завдяки тому, що полімер вже диспергований i потребує менше часу перемішування до повного об'єднання з бітумом.

Введення латексу Butonal NS 198 в бітум призводить до підвищення оптимального вмісту в'яжучого (в середньому на $0,5 \%$ ), що зв'язано зі збільшенням в'язкості самого в'яжучого.
Оптимальна кількість

в'яжучого

збільшується зі зменшенням вмісту щебеню, тобто при переході від асфальтобетону типу А до типу Г.

Застосування бітумів модифікованих латексами для виготовлення асфальтобетонів призводить до істотного і прогнозованого зростання показників міцності асфальтобетонів: міцності на стиск, зсувостійкості та міцності на розтяг.

Показники міцності на зсув на розтяг по твірній в більшій мірі, ніж показники міцності на стиск чутливі до вмісту в них полімеру: коефіцієнт підсилюючої дії 4 \% полімеру (для типу Б) по міцності на стиск при $50{ }^{\circ} \mathrm{C}$ дорівнює 1,30 , по опору на зсув та розтяг - 1,40 та 1,54 відповідно.

Добавка катіонного латексу Butonal NS 198 підвищує водостійкість асфальтобетону за рахунок наявності у латексі катіонного емульгатору та покращує зчеплюваємість бітуму з поверхнею мінеральних матеріалів.

\section{Список використаних джерел}

1. Золотарев В.А. Битумы, модифицированные полимерами, и асфальтополимербетоны [Текст] / В.А. Золотарев // Дорожная техника. - 2009. - № 1. - С. 16-23.

2. Zhu J. Polymer modification of bitumen: advances and challenges [Текст] / Zhu J., Birgisson B., Kringos N. // European Polymer Journal. - 2014. - Vol. 54. - P. 18-38.

3. Модифицированные битумные вяжущие, специальные битумы и битумы с добавками в дорожном строительстве [Текст] /перевод с франц. / Под редакцией д.т.н. В.А. Золоторёва, д.т.н. В.И. Братчуна. - Харьков: ХНАДУ, 2003.- 229 с.

4. Оцінка впливу модифікатора бітуму Бутонал NS 198 на підвищення довговічності асфальтобетонного покриття [Текст] / Макарчев О.О., Мозговий В.В., Бесараб О.М., Онищенко А. М. // Дороги і мости. Збірник наукових статей. ДерждорНДІ. - 2006. - № 5. - С. 275-288.

5. Al-Ameri M. Modification of residual bitumen from orhovytska oil by butonal polymeric latexes [Текст] / M. Al-Ameri, O. Grynyshyn, Y. Khlibyshyn // Chemistry \& chemical technology. - 2013. - Vol. 7, № 3. - P. 323-326.

6. Битумы нефтяные дорожные вязкие. Технические условия: ДСТУ 4044-2001. [Чинний від 2002-01-01]. - К.: Держстандарт. 2001. - 15 с. (Національний стандарт України).

7. Будівельні матеріали. Суміші асфальтобетонні $\mathrm{i}$ асфальтобетон дорожній $\mathrm{i}$ аеродромний: ДСТУ Б В.2.7-119:2011. [Чинний від 2012-10-01]. - К.: Мінрегіон України, 2012. - 42 с. (Національний стандарт України).

8. Будівельні матеріали. Бітуми дорожні, модифіковані полімерами. Технічні умови: ДСТУ Б В.2.7-135:2007. [Чинний від 2008-01-01]. - К.: Мінрегіонбуд України, 2007. - 26 с. (Національний стандарт України).

9. Рыбьев И.А. Асфальтовые бетоны [Текст] / И.А. Рыбьев. - М.: Высш. шк., 1969. - 399 c.

Рецензент: д.т.н., професор С.М. Толмачова

Оксак Сергій Володимирович канд. техн. наук, доцент кафедра технології дорожньо-будівельних матеріалів Харківський національний автомобільно-дорожній університет. Тел.: (057) 707-37-26. E-таіl: vvm@khadi.kharkov.ua 
Oksak Sergiy Volodymyrovych cand. of techn. sciences, associate professor department of technology roadconstruction materials Kharkiv National Automobile and Highway University. Tel.: (057) 707-37-26. E-mail: vvm@khadi.kharkov.ua 